\title{
About leak detection systems in the framework of LBB concept application at Russian NPPs
}

\author{
A.A. Arzhaev ${ }^{1}$, A.I. Arzhaev¹, V.O. Makhanev $^{1}$, M.I. Antonov ${ }^{2}$, A.V. Emelianov², A.A. Kalyutik ${ }^{2}$, Yu.E. Karyakin ${ }^{2}$, \\ K.A. Arzhaev ${ }^{3}$, I.N. Denisov ${ }^{3}$ \\ antonov-mi@yandex.ru | em-ant1990@yandex.ru | kalyutik@yandex.ru | yu kar@mail.ru | \\ arzhaev.alexander@yandex.ru | arjaev@,diaprok.msk.ru | v.makhanev@gmail.com | arzhaevk@insc.ru | denisov@,insc.ru \\ ${ }^{1}$ LLE "SPE “DIAPROK”, Moscow, Russia \\ ${ }^{2}$ Peter the Great St. Petersburg Polytechnic University, Sankt-Petersburg, Russia \\ ${ }^{3}$ ANO "International Nuclear Safety Center", Moscow, Russia
}

\begin{abstract}
Application of "leak before break" concept to reactor coolant circuit is obligatory for RF NPPs and the success depends also on fulfilment of requirements to the leak detection systems specified in RF national standard. During 1999-2020 requirements to the leak detection systems were permanently improved in regulatory documents. The most important changes in requirements have been done according to the Federal law on ensuring the uniformity of measurements. Paper gives comparative analyses of these evolutionary changes of requirements as well as details of their implementation during design and manufacturing of leak detection systems to supply NPP Units with VVER-440/1000/1200 and RBMK-1000 reactor facilities. Recently approved in the Russian Federation, the Federal norms and rules (FNR) in the field of atomic energy use ensure the continuity of the general requirements for reactor coolant leak monitoring (detection) systems (LDS) at nuclear power plants (NPPS) in relation to the previously valid regulatory documents.

Keywords: leak before break concept, leak detection system, certificates of approval of the type of measuring instrument, certified measuring procedure.
\end{abstract}

\section{Introduction}

Actual Russian Federal Norms and Rules (FNR) in the field of nuclear energy use [1-3] ensure continuity of general requirements for reactor coolant leak monitoring (detection) systems (LDS) at nuclear power plant (NPP) in relation to former regulatory documents [4-6].

Specific requirements for LDS were first defined in normative guidelines on the "leak before break" (LBB) concept [7] for use at Russian NPPs. The guideline [7] had been developed by the analogy with international practice of the LBB concept application: the publications [8-9] contain references to LDS manual [10].

\section{Requirements to LDS in 1999-2018}

The Federal Law on the unity of measurements No.102 [11] (2008) led to changes in the technical policy of Russian nuclear power industry. Indicator-type LDS (as was actually the case in [7]) gradually began to be replaced by measurement-type LDS with technical requirements providing explicitly the necessary characteristics of measurement accuracy.

It should be noted that the regulatory documents on LBB concept applications [7, 12-13] did not take into account the requirements for the LDS of the primary coolant, which were specified in paragraph 5.2.5 PNAE G01-036-95 (NP-006-98) [6] in relation to the detection of minimum leak through the pressure boundaries of the first circuit of the VVER type reactor: "specify the minimum amount of leakage that can be detected by the methods used." This requirement is fully contained in the current document NP-006-16 [3] in subsection 5.2.6 of the mandatory Annex No. 3.

The application of this requirement under the conditions of a complete ban on the operation of the NPP Unit with through wall defects in equipment and pipelines [14] provided the way to effective LDS transfer from the indicator status to the measuring one by metrological confirmation of the LDS characteristics: sensitivity $\mathrm{Q}_{0}$ (one of the main parameters used in the algorithms for proving the LBB concept in $[7,12-13]$ ) and the minimum leakage detected value $\mathrm{Q}_{\min }$ (should be evaluated for the LDS application).

The relationship of these parameters through the relative measurement error of leak flow rate $\delta$ can be written as $\mathrm{Q}_{\min }=(1+\delta) \mathrm{Q}_{0}$.

The normative guideline [12] specified, as metrological requirement, that "the relative error in measuring the leak flow rate (relative to the measured value) is not more than $\pm 50 \% "$.

Also [12] contained the requirement that "the LDS must ensure the reliability of leak control at a level not lower than 0.9. The reliability indicator of the LDS leak control must be justified in the design documentation for the system". The document [13] defined the indicator value equal to 0.8 .

In contrast to [12], [13] the national standard on the LBB concept application (GOST R 58328-18 [15], valid from 01.01.2019), has no any mention of the reliability indicator of the LDS leak control.

The requirements for the lower limit of LDS sensitivity $\mathrm{Q}_{0}-1.9 \mathrm{~kg} / \mathrm{min}$ for pipelines with $150 \leq \mathrm{D}_{\text {nom }}<750 \mathrm{~mm}$ and $3.8 \mathrm{~kg} / \mathrm{min}$ for pipelines with $\mathrm{D}_{\text {nom }} \geq 750 \mathrm{~mm}-$ are coincide in the regulatory documents [12-13, 15].

Results of comparing the LDS requirements specified by documents on LBB concept applications are presented in detail in table 1.

\section{Characteristics of VVER type LDS}

For NPP Units with VVER-440/1000, JSC IPPE developed LDS for the primary (SACT and SCTV) and secondary (SACT-2K, SCTV-2K and SCTV-2P) circuits in accordance with the technical specifications [16-17]. The LDS are characterized by relative error of $\pm 50 \%$ for 
the leak flow rate measurements (table 2). The listed LDS subsystems provide monitoring of leaks for pipelines under thermal insulation (except for SCTV-2P) using acoustic sensors and humidity control sensors, determining the leak location or the distance from the acoustic sensor to the leak location with absolute error $\pm 2 \mathrm{~m}$. The SCTV-2P subsystem is able to locate leak position up to the compartment of the NPP Unit. Certificates of approval of the type of measuring instrument (CATMI) have been issued for LDS subsystems of acoustic control and humidity control (table $2)$. These certificates confirm the minimum leakage detected value $Q_{\min }$ at least $1.51 / \mathrm{min}$. So requirements of the $[1-6]$ and $[12-13,15]$ are fulfilled.

Table 1. Comparison of requirements for LDS in Russian normative guidelines from 1999 year to present time

\begin{tabular}{|c|c|c|c|c|}
\hline Requirements for LDS & RD 95 10547-99 & \begin{tabular}{|c|} 
RD EO 1.1.2.05.0939- \\
2013
\end{tabular} & $\begin{array}{c}\text { RD EO 1.1.2.05.0939- } \\
2016\end{array}$ & GOST R 58328-2018 \\
\hline LDS status & $\begin{array}{l}\text { p.8.6.1: diagnostic } \\
\text { system }\end{array}$ & $\begin{array}{c}\text { p.5.3.3: measurement } \\
\text { system for technical } \\
\text { diagnostics }\end{array}$ & & \\
\hline $\begin{array}{l}\text { Requirement for intervention of } \\
\text { the NPP Unit control panel } \\
\text { operator in the operation of LDS }\end{array}$ & $\begin{array}{l}\text { p.8.6.2: } \\
\text { no requirements }\end{array}$ & & & \\
\hline $\begin{array}{l}\text { Requirement to separate leaks } \\
\text { from identified and unidentified } \\
\text { sources }\end{array}$ & yes & 5.1 .2 & no & no \\
\hline Number of subsystems in LDS & 3 & \begin{tabular}{|c|} 
p.5.3.1.1, item $2:$ \\
3 for primary circuit \\
2 for secondary circuit \\
\end{tabular} & $\begin{array}{l}\text { p.D.1.8 } \\
\text { at least } 3\end{array}$ & $\begin{array}{l}\text { p.B.1.2 and p.B.1.3 } \\
2+1 \text { (LDS Integral } \\
\text { Level) }\end{array}$ \\
\hline $\begin{array}{l}\text { Should leak monitoring be } \\
\text { performed based on the radiation } \\
\text { activity parameter? }\end{array}$ & $\begin{array}{c}\text { p.8.5, item 1: } \\
\text { yes }\end{array}$ & no & $\begin{array}{l}\text { p.D.1.8: } \\
\text { yes }\end{array}$ & $\begin{array}{l}\text { p.B.1.3: } \\
\text { yes }\end{array}$ \\
\hline $\begin{array}{l}\text { Requirements for LDS Integral } \\
\text { Level when NPP unit operating } \\
\text { at rated power: }\end{array}$ & Yes & yes & & p.B.2.3 \\
\hline - leak rate sensitivity is not worse & \begin{tabular}{|c|} 
p. 8.5, item $3:$ \\
$-3,81 /$ min (for the \\
reactor cooling \\
circuit) \\
$-191 /$ min (for steam \\
pipelines)
\end{tabular} & $\begin{array}{c}\text { p.5.3.1.5: } \\
-3,8 \mathrm{~kg} / \mathrm{min} \text { (for main } \\
\text { circulation pipelines) } \\
-1,9 \mathrm{~kg} / \mathrm{min} \text { (for other } \\
\text { pipelines) }\end{array}$ & $\begin{array}{c}\text { p.D.2.2, "a": } \\
-3,8 \mathrm{~kg} / \mathrm{min}\left(\mathrm{D}_{\text {nom }} \geq 750\right. \\
\mathrm{mm}) \\
-1,9 \mathrm{~kg} / \mathrm{min} \\
\left(150 \leq \mathrm{D}_{\text {nom }}<750 \mathrm{~mm}\right)\end{array}$ & $\begin{array}{c}\text { p.B. } 2.3 \text {, item } 1: \\
-3,8 \mathrm{~kg} / \mathrm{min}(228 \\
\mathrm{kg} / \text { hour }) \text { for pipelines } \\
\mathrm{D}_{\text {nom }} \geq 750 \mathrm{~mm} ; \\
-1,9 \mathrm{~kg} / \mathrm{min}(114 \\
\mathrm{kg} / \text { hour }) \text { for pipelines } \\
150 \leq \mathrm{D}_{\text {nom }}<750 \mathrm{~mm}\end{array}$ \\
\hline $\begin{array}{l}\text { - the upper range of leak flow } \\
\text { measurement }\end{array}$ & not established & not established & $\begin{array}{c}\text { p.D.2.2, "b)": } \\
\text { at least } 19,0 \mathrm{~kg} / \mathrm{min}\end{array}$ & $\begin{array}{l}\text { p.B.2.3, item 2: } \\
\text { at least } 19,0 \mathrm{~kg} / \mathrm{min}\end{array}$ \\
\hline $\begin{array}{l}\text { - the time interval of the } \\
\text { detection and measurement of } \\
\text { leaks }\end{array}$ & $\begin{array}{c}\text { p. } 8.5 \text {, item } 3: \\
\text { no more than } 1 \text { hour }\end{array}$ & $\begin{array}{c}\text { p.5.3.1.5: } \\
\text { no more than } 1 \text { hour } \\
\text { (as possible) } \\
\end{array}$ & $\begin{array}{l}\text { p.D.2.2., "v)" } \\
\text { no more than } 1 \text { hour }\end{array}$ & $\begin{array}{l}\text { p.B.2.3, item } 3 \text { : } \\
\text { no more than } 1 \text { hour }\end{array}$ \\
\hline $\begin{array}{l}\text { - the relative error of a leak flow } \\
\text { measurement }\end{array}$ & $\begin{array}{l}\text { don't need to } \\
\text { specify }\end{array}$ & \begin{tabular}{|}
$\quad$ p.5.3.1.5: \\
reduced (modified) to \\
the measured value, \\
no more than $\pm 50 \%$
\end{tabular} & $\begin{array}{c}\text { p.D.2.2, "g)": } \\
\text { no more than } \pm 50 \%\end{array}$ & $\begin{array}{c}\text { p.B. } 2.3 \text {, item } 4: \\
\text { no more than } \pm 50 \%\end{array}$ \\
\hline $\begin{array}{l}\text { - error in measuring the leak } \\
\text { location coordinates }\end{array}$ & $\begin{array}{l}\text { p. } 8.5 \text {, item } 3: \\
\text { recommendation } \\
\quad \pm 2 \mathrm{~m} \\
\end{array}$ & $\begin{array}{l}\text { p.5.3.1.5: } \\
\quad \pm 2 \mathrm{~m}\end{array}$ & \begin{tabular}{|c|} 
p.D. 2.2, "d)": \\
no more than $\pm 2 \mathrm{~m}$ or $1 / 2$ \\
of placing sensors step \\
\end{tabular} & $\begin{array}{c}\text { B.2.3, item } 5: \\
\pm 3 \text { m, but no more than } \\
1 / 2 \text { of placing sensors step }\end{array}$ \\
\hline $\begin{array}{l}\text { The requirement to LDS at the } \\
\text { lowest recorded flow rate of } \\
\text { unidentified leakage }\end{array}$ & no & $\begin{array}{c}\text { p.5.3.1.5: } \\
-230 \mathrm{~kg} / \mathrm{min} \text { (for main } \\
\text { circulation pipelines) } \\
-114 \mathrm{~kg} / \text { min (for other } \\
\text { pipelines) }\end{array}$ & & no \\
\hline $\begin{array}{l}\text { The requirement to LDS to } \\
\text { function in the mode of hydraulic } \\
\text { (pneumatic) tests }\end{array}$ & p.8.1, paragraph 2 & no & p.D.1.13 & no \\
\hline $\begin{array}{l}\text { The requirement to LDS to } \\
\text { function in regimes of NNUE } \\
\text { and accident situation }\end{array}$ & no & p.5.1.2 & & no \\
\hline \begin{tabular}{|l|} 
The requirement to LDS to detect \\
and identify leaks of equipment \\
and pipelines when the unit is
\end{tabular} & no & no & & p.B.1.1 \\
\hline
\end{tabular}




\begin{tabular}{|c|c|c|c|c|}
\hline Requirements for LDS & RD 95 10547-99 & \begin{tabular}{|c|} 
RD EO 1.1.2.05.0939- \\
2013
\end{tabular} & $\begin{array}{l}\text { RD EO 1.1.2.05.0939- } \\
2016\end{array}$ & GOST R 58328-2018 \\
\hline \multicolumn{5}{|l|}{$\begin{array}{l}\text { operating in start-up (stop) } \\
\text { modes) }\end{array}$} \\
\hline $\begin{array}{l}\text { Need to approve the type of } \\
\text { measuring instrument on LDS }\end{array}$ & no & $\begin{array}{l}\text { p.5.3.4.1: } \\
\text { yes }\end{array}$ & $\begin{array}{l}\text { p.D.3.3 }{ }^{5)} \text { : } \\
\text { yes }\end{array}$ & $\begin{array}{l}\text { p.B.2.5: } \\
\text { yes }\end{array}$ \\
\hline $\begin{array}{l}\text { Separate requirement for approval } \\
\text { of the type of measuring } \\
\text { instrument to measuring channels }\end{array}$ & no & no & $\begin{array}{l}\text { p.D.3.2 } \\
\quad \text { yes }\end{array}$ & no \\
\hline $\begin{array}{l}\text { Requirements for reliability of } \\
\text { leak detection }\end{array}$ & $\begin{array}{c}\text { p.8.6.1: } \\
\text { requirements to } \\
\text { minimize: } \\
\text { - the probabilities of } \\
\text { false operation; } \\
\text { - probability of } \\
\text { missing an event }\end{array}$ & $\begin{array}{c}\text { p.5.3.2: } \\
\text { not less than } 0.9\end{array}$ & $\begin{array}{c}\text { p.D.2.2, "e": not less than } \\
0.8 \text { (in the flow rate range } \\
\text { from the lower limit to the } \\
\text { middle of the } \\
\text { measurement range); } \\
\text { below } 0.9 \text { (if the flow rate } \\
\text { is above the middle of the } \\
\text { measurement range) }\end{array}$ & no \\
\hline $\begin{array}{l}\text { Requirement to LDS to specify } \\
\text { the minimum leakage value that } \\
\text { must be detected using the } \\
\text { methods used (from NP-006-98 } \\
\text { and NP-006-16) }\end{array}$ & no & no & no & p.6.2.3 \\
\hline $\begin{array}{l}\text { The method for measuring leak } \\
\text { parameters should be developed } \\
\text { in accordance with the } \\
\text { requirements of GOST R 8.932- } \\
2017\end{array}$ & no & no & no & p.B.2.1 \\
\hline $\begin{array}{l}\text { LDS software must be verified } \\
\text { and passed the procedure for } \\
\text { confirming compliance with the } \\
\text { requirements of GOST R 8.654- } \\
2009\end{array}$ & no & no & no & p.B.2.2 \\
\hline \begin{tabular}{lll} 
Requirement & for & \multicolumn{2}{c}{ certification } \\
LDS software/software & tool in \\
Rostechnadzor & bodies & in \\
accordance & with & current \\
requirements & &
\end{tabular} & no & $\begin{array}{l}\text { p.5.3.3: } \\
\text { yes }\end{array}$ & no & no \\
\hline $\begin{array}{l}\text { Seismic qualification requirement } \\
\text { for each LDS subsystem }\end{array}$ & \begin{tabular}{|c|} 
p.8.7.1, item $4:$ \\
yes; \\
p.8.9 - see below ${ }^{1}:$
\end{tabular} & no & no & no \\
\hline $\begin{array}{l}\text { Requirement for identification } \\
\text { and seismic qualification of AC } \\
\text { power sources for each LDS }\end{array}$ & $\begin{array}{l}\text { p.8.7.1, item 6: yes } \\
\text { p.8.9 - see below }\end{array}$ & no & no & no \\
\hline $\begin{array}{l}\text { The requirement to ensure the } \\
\text { possibility of calibration of } \\
\text { measuring channels in the } \\
\text { operating mode }\end{array}$ & $\begin{array}{l}\text { p.8.10: } \\
\text { yes }\end{array}$ & no & no & no \\
\hline
\end{tabular}

Table. 2. The list of CATMI for LDS of NPPs with VVER type reactor

\begin{tabular}{|c|c|c|c|c|c|}
\hline Reg. ID & Name of measuring instrument & $\begin{array}{l}\text { Valid until/ } \\
\text { Verification } \\
\text { interval }\end{array}$ & $\begin{array}{c}\text { The system consists } \\
\text { of } \text { LDS }^{3} \text { / Technical } \\
\text { specification }\end{array}$ & $\mathbf{Q}_{\min } / \delta^{4}$ & \begin{tabular}{|c} 
Limits of permissible absolute \\
error in determining the leak \\
site
\end{tabular} \\
\hline $\begin{array}{c}55686- \\
13\end{array}$ & $\begin{array}{l}\text { Acoustic LDS with acoustic signal } \\
\text { measurement channels } \\
\text { Manufacturer (Vendor): IPPE JSC } \\
\text { https://info.metrologu.ru/grsi/grsi 225869.html }\end{array}$ & $\begin{array}{l}28.11 .2018 \\
09.04 .2023 / \\
2 \text { years }\end{array}$ & $\begin{array}{c}\text { Technical } \\
\text { specification } \\
\text { E.091.7372.05 TU }\end{array}$ & $\begin{array}{c}1,51 / \mathrm{min} \\
\pm 50 \%\end{array}$ & $\begin{array}{c} \pm 2 \mathrm{~m} \text { (Limits of permissible } \\
\text { absolute error in determining } \\
\text { the distance from the acoustic } \\
\text { sensor to the leak site) }\end{array}$ \\
\hline
\end{tabular}

\footnotetext{
${ }^{1}$ The drainage level monitoring system and at least one of the three leak monitoring subsystems must be qualified to perform the design functions corresponding to the maximum design earthquake for NPP Unit;

${ }^{2}$ The earthquake-resistant LDS must be powered from a earthquake-resistant AC power source

${ }^{3}$ LDS in the table 2 meet the requirements of NP-006-98, NP-006-16 and p.6.2.3 of GOST R 58328-2018.

${ }^{4} \mathrm{Q}_{\min }$ - Minimum detectable amount of coolant flow through a leak; $\delta$ - Limits of permissible relative error in determining the flow rate of the coolant through a leak, $\%$
} 


\begin{tabular}{|c|c|c|c|c|c|}
\hline Reg. ID & Name of measuring instrument & $\begin{array}{l}\text { Valid until/ } \\
\text { Verification } \\
\text { interval }\end{array}$ & \begin{tabular}{|c|} 
The system consists \\
of LDS $^{3}$ / Technical \\
specification
\end{tabular} & $\mathbf{Q}_{\min } / \delta^{4}$ & $\begin{array}{c}\text { Limits of permissible absolute } \\
\text { error in determining the leak } \\
\text { site }\end{array}$ \\
\hline \multirow{2}{*}{$\begin{array}{c}55687- \\
13\end{array}$} & \multirow{2}{*}{$\begin{array}{l}\text { LDS with relative humidity and temperature } \\
\text { measurement channels } \\
\text { Manufacturer (Vendor): IPPE JSC } \\
\text { https://info.metrologu.ru/grsi/grsi 226346.html }\end{array}$} & \multirow{2}{*}{$\begin{array}{l}28.11 .2018 \\
11.04 .2023 / \\
2 \text { years }\end{array}$} & \begin{tabular}{|} 
SCTV, SCTV-2K \\
/ Technical \\
specification \\
E.091.7326.01 TU
\end{tabular} & \multirow{2}{*}{$\begin{array}{l}1,0 \mathrm{l} / \mathrm{min} \\
\pm 50 \%\end{array}$} & $\pm 2 \mathrm{~m}$ \\
\hline & & & \begin{tabular}{|c|} 
SCTV-2P / \\
Technical \\
specification \\
E.091.7326.01 TU
\end{tabular} & & $\begin{array}{c}\langle\ll-» \\
\text { accurate to the room }\end{array}$ \\
\hline
\end{tabular}

\section{Characteristics of RBMK type LDS}

Full-scale LDS for RBMK NPP Units - ASOTT - were developed by NIKIET JSC. The details of certified measuring procedures (CMP) for full-scale LDS at four RBMK NPP Units are provided in table 3.

The CMPs (FR.1.29.2016.24188 FR.1.29.2016.24191) contain formulas to calculate flow rate measurement error as applied to individual subsystems and LDS as a whole. The formulas are the same for Units of the first and second generations of RBMK NPPs, which have differences in layout of technological equipment. The formulas do not take into account presence or absence of thermal insulation on piping outer surface. Calculations using these formulas, as applied to full-scale LDS give for the lower flow rate boundary $114 \mathrm{~kg} / \mathrm{h}$ the corresponding relative error equal to $\pm 75 \%$, and for the upper boundary $1140 \mathrm{~kg} / \mathrm{h}$ the corresponding relative error equal to $\pm 65 \%$. In other words, the threshold of $\pm 50 \%$ specified by the regulatory documents $[12-13,15]$ has been exceeded.

For LDS of other two RBMK NPP Units (Smolensk NPP Unit 1, Kursk NPP Unit 3) CATMI have been issued also (tables 4 and 5). Formulas to calculate flow rate measuring errors of individual subsystems and LDS as a whole specified in the CATMI (tables 4 and 5) are similar to the ones specified in CMP (table 3). Therefore, the estimates given above are valid and also do not meet the requirements of regulatory documents $[12-13,15]$.

Table 3. The list of CMP for LDS of NPPs with RBMK type reactor

\begin{tabular}{|c|c|c|c|c|c|}
\hline Registration ID & Name of the CMP & $\begin{array}{c}\text { Certificate of } \\
\text { attestation }\end{array}$ & Issue date & $\begin{array}{l}\text { Measurement } \\
\text { range, kg/hour }\end{array}$ & $\begin{array}{l}\text { Number of } \\
\text { measuring } \\
\text { channels }\end{array}$ \\
\hline FR.1.29.2016.24191 & $\begin{array}{l}\text { Measurement procedure for measuring mass flow and } \\
\text { determining the leak location coordinates using the } \\
\text { coolant full-scaled automatic leak detection system of } \\
\text { Smolensk NPP Unit } 2 \\
\text { https://fgis.gost.ru/fundmetrology/registry/16/items/2970 } \\
39\end{array}$ & \begin{tabular}{|c|}
$01.00225-$ \\
$2011.201 / 056$ \\
-2015
\end{tabular} & 18.12 .2015 & $114 \div 1140$ & 4 \\
\hline FR.1.29.2016.24190 & $\begin{array}{l}\text { Measurement procedure for measuring mass flow and } \\
\text { determining the leak location coordinates using the } \\
\text { coolant full-scaled automatic leak detection system of } \\
\text { Kursk NPP Unit } 4 \\
\text { https://fgis.gost.ru/fundmetrology/registry/16/items/2970 } \\
38\end{array}$ & \begin{tabular}{|c|}
$201-$ \\
$007 / 01.00225$ \\
$-2011 / 2016$
\end{tabular} & 29.04 .2016 & $114 \div 1140$ & 4 \\
\hline FR.1.29.2016.24189 & $\begin{array}{l}\text { Measurement procedure for measuring mass flow and } \\
\text { determining the leak location coordinates using the } \\
\text { coolant full-scaled automatic leak detection system of } \\
\text { Kursk NPP Unit } 2 \\
\text { https://fgis.gost.ru/fundmetrology/registry/16/items/2970 } \\
37\end{array}$ & \begin{tabular}{|c|}
$201-$ \\
$005 / 01.00225$ \\
$-2011 / 2016$
\end{tabular} & 08.04.2016 & $114 \div 1140$ & 3 \\
\hline FR.1.29.2016.24188 & $\begin{array}{l}\text { Measurement procedure for measuring mass flow and } \\
\text { determining the leak location coordinates using the } \\
\text { coolant full-scaled automatic leak detection system of } \\
\text { Kursk NPP Unit 1 } \\
\text { https://fgis.gost.ru/fundmetrology/registry/16/items/2970 } \\
\underline{36}\end{array}$ & \begin{tabular}{|c|}
$201-$ \\
$008 / 01.00225$ \\
$-2011 / 2016$
\end{tabular} & 13.04 .2016 & $114 \div 1140$ & 3 \\
\hline
\end{tabular}

Table 4. The list of CATMI for LDS of Smolensk NPP Unit 1 with RBMK type reactor

\begin{tabular}{|c|l|c|c|c|c|}
\hline \multirow{2}{*}{ Registration ID } & Name of CATMI /Technical specification & $\begin{array}{c}\text { Data of the } \\
\text { approval } \\
\text { certificate of } \\
\text { CATMI }\end{array}$ & $\begin{array}{c}\text { Valid until / } \\
\text { Verification } \\
\text { interval }\end{array}$ & $\begin{array}{c}\text { Measurement } \\
\text { range, } \mathbf{k g} / \mathbf{h o u r}\end{array}$ & $\begin{array}{c}\text { Number of } \\
\text { measuring } \\
\text { channels }\end{array}$ \\
\hline \multirow{3}{*}{$57990-14$} & $\begin{array}{l}\text { Full-scaled automatic leak detection system of reactor coolant } \\
\text { of Smolensk NPP Unit 1 / No technical specifications } \\
\text { https://fgis.gost.ru/fundmetrology/registry/4/items/370946 }\end{array}$ & $\begin{array}{c}\text { RU.E.29.004.A } \\
\text { №56250/ } \\
23.07 .2014\end{array}$ & $\begin{array}{c}\text { unlimited/ } \\
1 \text { year }\end{array}$ & $114 \div 1140$ & 4 \\
\hline
\end{tabular}

\footnotetext{
${ }^{1}$ Measuring channel which characterized the specific way to leak detection (for example, humidity etc.)
} 
Table 5. The list of CATMI for LDS of Kursk NPP Unit 3 with RBMK type reactor

\begin{tabular}{|c|c|c|c|c|c|}
\hline Registration ID & Name of CATMI/Technical specification & $\begin{array}{l}\text { Data of the } \\
\text { approval } \\
\text { certificate of } \\
\text { CATMI }\end{array}$ & $\begin{array}{l}\text { Valid until / } \\
\text { Verification } \\
\text { interval }\end{array}$ & $\begin{array}{c}\text { Measurement } \\
\text { range, kg/hour }\end{array}$ & $\begin{array}{l}\text { Number of } \\
\text { measuring } \\
\text { channels }\end{array}$ \\
\hline $58802-14$ & $\begin{array}{l}\text { Subsystem of ASOTT-V (ASOTT-humidity) of Kursk } \\
\text { NPP Unit 3 / TU 4389-007-73555750-2012 } \\
\text { https://fgis.gost.ru/fundmetrology/registry/4/items/371903 }\end{array}$ & $\begin{array}{l}\text { RU.E.29.004.A } \\
\text { №57125/ } \\
20.10 .2014\end{array}$ & $\begin{array}{c}\text { unlimited / } 1 \\
\text { year }\end{array}$ & $114 \div 1140$ & - \\
\hline $58803-14$ & $\begin{array}{l}\text { Subsystem of ASOTT-T (ASOTT-Temperature) of Kursk } \\
\text { NPP Unit } 3 \text { / TU 4389-008-73555750-2012 } \\
\text { https://fgis.gost.ru/fundmetrology/registry/4/items/371904 }\end{array}$ & $\begin{array}{l}\text { RU.E.29.004.A } \\
\text { №57153 / } \\
20.10 .2014\end{array}$ & $\begin{array}{c}\text { unlimited / } 1 \\
\text { year }\end{array}$ & $114 \div 1140$ & - \\
\hline $58804-14$ & $\begin{array}{l}\text { Subsystem of ASOTT-A of Kursk NPP Unit } 3 \text { / TU 4389- } \\
\text { 006-73555750-2012 } \\
\text { https://fgis.gost.ru/fundmetrology/registry/4/items/371905 }\end{array}$ & $\begin{array}{l}\text { RU.E.29.050.A } \\
\text { №57154 / } \\
20.10 .2014\end{array}$ & $\begin{array}{c}\text { unlimited / } 1 \\
\text { year }\end{array}$ & $114 \div 1140$ & - \\
\hline $58805-14$ & \begin{tabular}{|l|} 
Subsystem of ASOTT-Ac (ASOTT-acoustic) of Kursk \\
NPP Unit 3 / TU 4389-009-73555750-2012 \\
https://fgis.gost.ru/fundmetrology/registry/4/items/371906
\end{tabular} & $\begin{array}{l}\text { RU.E.29.004.A } \\
\text { №57155 / } \\
20.10 .2014\end{array}$ & $\begin{array}{c}\text { unlimited / } 1 \\
\text { year }\end{array}$ & $114 \div 1140$ & - \\
\hline 58806-14 & $\begin{array}{l}\text { Full-scaled automated LDS of Kursk NPP Unit 3 / TU } \\
\text { 4389-010-73555750-2012 } \\
\text { https://fgis.gost.ru/fundmetrology/registry/4/items/371907 }\end{array}$ & $\begin{array}{l}\text { RU.E.29.004.A } \\
\text { №57156/ } \\
20.10 .2014\end{array}$ & $\begin{array}{c}\text { unlimited / } 1 \\
\text { year }\end{array}$ & $114 \div 1140$ & 4 \\
\hline
\end{tabular}

Information and formulas provided in CMPs (table 3) for each LDS measuring channel to assess flow rate measurement error and values of $\mathrm{Q}_{\min }$ as applied to individual subsystems and LDS as a whole are given in table 6. Estimations of flow rate measurement error and values of $\mathrm{Q}_{\min }$ for a set of $\mathrm{G}$ values are provided in table 7.

Table 6. Measuring channel set for ASOTT-P for NPPs with RBMK type reactor

Table 6. Measuring channel set for ASOTT-P for NPPs with RBMK type reactor
\begin{tabular}{|l|c|c|}
\hline \multicolumn{1}{|c}{ Measuring channel / ASOTT-P } & $\begin{array}{c}\text { Measurement range, } \\
\text { kg/hour }\end{array}$ & $\begin{array}{c}\text { Limits of the relative measurement error } \\
\text { interval corresponding to P }=\mathbf{0 . 9 5}\end{array}$ \\
\hline $\begin{array}{l}\text { Measuring channel of mass leak flow rate based on } \\
\text { direct temperature measurement (subsystem ASOTT-T) }\end{array}$ & $114 \div 1140$ & $\delta= \pm\left(0,2+\frac{4,2 \cdot\left(G_{\mathrm{B}}-G_{\mathrm{H}}\right)}{G+5,88 \cdot\left(G_{\mathrm{B}}-G_{\mathrm{H}}\right)}\right) \cdot 100$ \\
\hline $\begin{array}{l}\text { Measuring channel of mass leak flow rate based on } \\
\text { direct temperature and humidity measurement } \\
\text { (subsystem ASOTT-V) }\end{array}$ & $114 \div 1140$ & $\delta= \pm\left(0,2+\frac{3 \cdot\left(G_{\mathrm{B}}-G_{\mathrm{H}}\right)}{G+4,88 \cdot\left(G_{\mathrm{B}}-G_{\mathrm{H}}\right)}\right) \cdot 100$ \\
\hline $\begin{array}{l}\text { Measuring channel of mass leak flow rate based on the } \\
\text { results of direct measurements of the volume activity of } \\
\text { radioactive aerosols (subsystem ASOTT-A) }\end{array}$ & $114 \div 1140$ & $\delta= \pm\left(0,2+\frac{4,2 \cdot\left(G_{\mathrm{B}}-G_{\mathrm{H}}\right)}{G+5,88 \cdot\left(G_{\mathrm{B}}-G_{\mathrm{H}}\right)}\right) \cdot 100$ \\
\hline $\begin{array}{l}\text { Measuring channel of mass leak flow rate based on the } \\
\text { results of direct measurements of the sound pressure } \\
\text { level (subsystem ASOTT-A) }\end{array}$ & $114 \div 1140$ & $\delta= \pm\left(0,2+\frac{3,58 \cdot\left(G_{\mathrm{B}}-G_{\mathrm{H}}\right)}{G+5,38 \cdot\left(G_{\mathrm{B}}-G_{\mathrm{H}}\right)}\right) \cdot 100$ \\
\hline $\begin{array}{l}\text { Measuring channel of mass leak flow rate based on the } \\
\text { measurement results ASOTT-P }\end{array}$ & $114 \div 1140$ & $\delta= \pm\left(0,3+\frac{1,58 \cdot\left(G_{\mathrm{B}}-G_{\mathrm{H}}\right)}{G+3,38 \cdot\left(G_{\mathrm{B}}-G_{\mathrm{H}}\right)}\right) \cdot 100$ \\
\hline
\end{tabular}

* $\mathrm{G}$ - value of the measured mass leak flow rate, $\mathrm{kg} /$ hour; GB and $\mathrm{GH}$ - upper and lower level of measurement range of mass leak flow rate, $\mathrm{kg}$ /hour; $\mathrm{P}$ - confidence probability.

The time between the leak occurrence and the output of the measurement result with the specified error does not exceed 1 hour

Table 7. Calculating of $\mathrm{Q}_{\min }$ as $\left[\mathrm{G}_{\min } \mathrm{x}(1+\delta)\right]$ for ASOTT-P of NPP Units with RBMK type reactor

\begin{tabular}{|c|c|c|c|c|c|c|c|}
\hline & & & $\mathrm{G}$ & $114 \mathrm{~kg} / \mathrm{h}$ & $228 \mathrm{~kg} / \mathrm{h}$ & $627 \mathrm{~kg} / \mathrm{h}$ & $1140 \mathrm{~kg} / \mathrm{h}$ \\
\hline \multirow{2}{*}{ ASOTT-T } & KNPP-4 & FR.1.29.2016.24190 & \multirow{2}{*}{$\delta$} & \multirow{2}{*}{ $\pm 90,0 \%$} & \multirow{2}{*}{ $\pm 89,0 \%$} & \multirow{2}{*}{ $\pm 85,0 \%$} & \multirow{2}{*}{ $\pm 80,0 \%$} \\
\hline & SNPP-2 & FR.1.29.2016.24191 & & & & & \\
\hline \multirow{4}{*}{ ASOTT-V } & KNPP-1 & FR.1.29.2016.24188 & \multirow{4}{*}{$\delta$} & \multirow{4}{*}{ $\pm 80,0 \%$} & \multirow{4}{*}{ $\pm 79,0 \%$} & \multirow{4}{*}{ $\pm 75,0 \%$} & \multirow{4}{*}{ $\pm 70,0 \%$} \\
\hline & KNPP-2 & FR.1.29.2016.24189 & & & & & \\
\hline & KNPP-4 & FR.1.29.2016.24190 & & & & & \\
\hline & SNPP-2 & FR.1.29.2016.24191 & & & & & \\
\hline \multirow{4}{*}{ ASOTT-A } & KNPP-1 & FR.1.29.2016.24188 & \multirow{4}{*}{$\delta$} & \multirow{4}{*}{ $\pm 90,0 \%$} & \multirow{4}{*}{ $\pm 89,0 \%$} & \multirow{4}{*}{ $\pm 86,0 \%$} & \multirow{4}{*}{ $\pm 80,0 \%$} \\
\hline & KNPP-2 & FR.1.29.2016.24189 & & & & & \\
\hline & KNPP-4 & FR.1.29.2016.24190 & & & & & \\
\hline & SNPP-2 & FR.1.29.2016.24191 & & & & & \\
\hline \multirow{4}{*}{ ASOTT-Ak } & KNPP-1 & FR.1.29.2016.24188 & \multirow{4}{*}{$\delta$} & \multirow{4}{*}{ $\pm 85,0 \%$} & \multirow{4}{*}{ $\pm 84,0 \%$} & \multirow{4}{*}{ $\pm 80,0 \%$} & \multirow{4}{*}{ $\pm 75,0 \%$} \\
\hline & KNPP-2 & FR.1.29.2016.24189 & & & & & \\
\hline & KNPP-4 & FR.1.29.2016.24190 & & & & & \\
\hline & SNPP-2 & FR.1.29.2016.24191 & & & & & \\
\hline ASOTT-P & KNPP-1 & FR.1.29.2016.24188 & & & & & \\
\hline
\end{tabular}




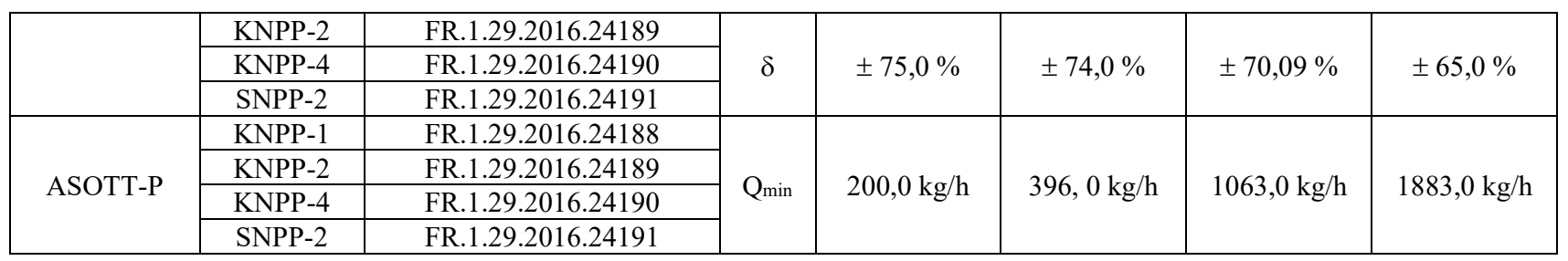

Information and formulas provided in CATMI (tables 4 and 5) for each LDS measuring channel to assess flow rate measurement error and values of $Q_{\min }$ as applied to individual subsystems and LDS as a whole are given in table 6 due to the fact that they are the same for CATMI and SMP. Estimations of flow rate measurement error and values of $\mathrm{Q}_{\min }$ for a set of $\mathrm{G}$ values are provided in table 8 .

Table 8. Calculating of $\mathrm{Q}_{\min }$ as $\left[\mathrm{G}_{\min } \mathrm{x}(1+\delta)\right]$ for ASOTT-P of SNPP Unit 1 and KNPP Unit 3

\begin{tabular}{|c|c|c|c|c|c|c|c|}
\hline & & & & & & & \\
\hline & & & $\mathrm{G}_{\mathrm{H}}$ & $114 \mathrm{~kg} / \mathrm{h}$ & $114 \mathrm{~kg} / \mathrm{h}$ & $114 \mathrm{~kg} / \mathrm{h}$ & $114 \mathrm{~kg} / \mathrm{h}$ \\
\hline & & & $\mathrm{G}_{\mathrm{B}}$ & $1140 \mathrm{~kg} / \mathrm{h}$ & $1140 \mathrm{~kg} / \mathrm{h}$ & $1140 \mathrm{~kg} / \mathrm{h}$ & $1140 \mathrm{~kg} / \mathrm{h}$ \\
\hline & & & $\mathrm{G}$ & $114 \mathrm{~kg} / \mathrm{h}$ & $228 \mathrm{~kg} / \mathrm{h}$ & $627 \mathrm{~kg} / \mathrm{h}$ & $1140 \mathrm{~kg} / \mathrm{h}$ \\
\hline \multirow{2}{*}{ ASOTT-T } & SNPP-1 & 57990-14 / RU.E.29.004.A №56250 & \multirow[b]{2}{*}{$\delta$} & \multirow{2}{*}{ $\pm 90,0 \%$} & \multirow{2}{*}{ $\pm 89,0 \%$} & \multirow[b]{2}{*}{ $\pm 85,0 \%$} & \multirow{2}{*}{ $\pm 80,0 \%$} \\
\hline & KNPP-3 & 58803-14 / RU.E.29.004.A №57153 & & & & & \\
\hline \multirow{2}{*}{ ASOTT-V } & SNPP-1 & 57990-14 / RU.E.29.004.A №56250 & \multirow[b]{2}{*}{$\delta$} & \multirow{2}{*}{ $\pm 80,0 \%$} & \multirow{2}{*}{ $\pm 79,0 \%$} & \multirow{2}{*}{ $\pm 75,0 \%$} & \multirow{2}{*}{ $\pm 70,0 \%$} \\
\hline & KNPP-3 & 58802-14 / RU.E.29.004.A №57125 & & & & & \\
\hline \multirow{2}{*}{ ACOTT-A } & SNPP-1 & 57990-14 / RU.E.29.004.A №56250 & \multirow[b]{2}{*}{$\delta$} & \multirow{2}{*}{ $\pm 90,0 \%$} & \multirow{2}{*}{ $\pm 89,0 \%$} & \multirow{2}{*}{ $\pm 86,0 \%$} & \multirow{2}{*}{ $\pm 80,0 \%$} \\
\hline & KNPP-3 & 58804-14 / RU.E.29.050.A №57154 & & & & & \\
\hline \multirow{2}{*}{ ASOTT-Ak } & SNPP-1 & 57990-14 / RU.E.29.004.A №56250 & \multirow[b]{2}{*}{$\delta$} & \multirow{2}{*}{ $\pm 85,0 \%$} & \multirow{2}{*}{ $\pm 84,0 \%$} & \multirow{2}{*}{ $\pm 80,0 \%$} & \multirow{2}{*}{ $\pm 75,0 \%$} \\
\hline & KNPP-3 & 58805-14 / RU.E.29.004.A №57155 & & & & & \\
\hline \multirow{2}{*}{ ASOTT-P } & SNPP-1 & 57990-14 / RU.E.29.004.A №56250 & \multirow{2}{*}{$\delta$} & \multirow{2}{*}{ $\pm 75,0 \%$} & \multirow{2}{*}{ $\pm 74,0 \%$} & \multirow{2}{*}{ $\pm 70,1 \%$} & \multirow{2}{*}{ $\pm 65,0 \%$} \\
\hline & KNPP-3 & 58806-14 / RU.E.29.004.A №57156 & & & & & \\
\hline \multirow{2}{*}{ ASOTT-P } & SNPP-1 & 57990-14 / RU.E.29.004.A №56250 & \multirow{2}{*}{$Q_{\min }$} & \multirow{2}{*}{$200,0 \mathrm{~kg} / \mathrm{h}$} & \multirow{2}{*}{$396,0 \mathrm{~kg} / \mathrm{h}$} & \multirow{2}{*}{$1063,0 \mathrm{~kg} / \mathrm{h}$} & \multirow{2}{*}{$1883,0 \mathrm{~kg} / \mathrm{h}$} \\
\hline & KNPP-3 & 58806-14 / RU.E.29.004.A №57156 & & & & & \\
\hline
\end{tabular}

The results discussed above indicate existing deviations from the requirements of [15] at seven RBMK NPP Units and absence of official data for LDS status of Leningrad Units 2-4 with RBMK.

The non-compliance of LDS at NPP Units with the requirements of GOST R 58328-2018 [15] violates compliance of these NPP Units with the requirements of paragraph 3.3.3 of NP-001-15 [1] and, consequently, noncompliance with the requirements of paragraph 21 of NP010-16 [18] remains uncompensated by improper LBB application. This situation as well as other deficiencies in the LBB concept applications at NPP Units as stated in the report [19] seems worth to be discussed with the Utility and NPP staff.

\section{Conclusion}

The article considers the evolution of requirements to LDS in Russian regulatory documents in 1999-2020.

The article provides details about LDS status at VVER and RBMK NPPs as certified measuring instrument for LBB application according to GOST R 58328-2018.

Some deviations from the actual requirements are highlighted and recommended for further discussion and improvement.

\section{Acknowledgment}

The reported study was funded by RFBR according to the research project № 19-07-00455.

\section{References}

[1] NP-001-15. General Safety Provisions for Nuclear Power Plants.
https://files.stroyinf.ru/Index2/1/4293756/429375690 $\underline{0 . h t m}$.

[2] NP-082-07. Investigation and Accounting of Abnormalities in the Course of Materials Accounting and Control at Nuclear Facilities. https://files.stroyinf.ru/Data1/52/52470/.

[3] NP-006-16. Requirements to Safety Analysis Report of Storage Facilities for Nuclear Materials. https://files.stroyinf.ru/Index2/1/4293745/429374556 9.htm.

[4] NP-001-97 (PNAE G-01-011-97). General provisions for assurance of safety at nuclear power stations OPB88/97. http://docs.cntd.ru/document/1200048646.

[5] PNAE G-1-024-90. Nuclear safety rules for reactors of nuclear power plants. http://docs.cntd.ru/document/471809874.

[6] NP-006-98 (PNAE G-01-036-95). Requirements to the contents of safety analysis report for a nuclear power plant with VVER-type reactor. http://docs.cntd.ru/document/1200054204.

[7] RD 95 10547-99 Guidance on the application of the LBB concept for NPP piping

[8] US NRC. NUREG-0800 SRP 3.6.3. LBB Evaluation Procedures, March 1987.

[9] US NRC. NUREG-0800 SRP 3.6.3. LBB Evaluation Procedures, March 2007.

[10] Regulatory Guide 1.45, «Reactor Coolant Pressure Boundary Leakage Detection Systems».

[11] Federal law «On ensuring the uniformity of measurements» N102-FZ from 26.08.2008 (with changes).

[12] JSC Rosenergoatom. RD EO 1.1.2.05.0939-2013.

[13] JSC Rosenergoatom. RD EO 1.1.2.05.0939-2016. 
[14] PNAE G-7-008-89. Rules of arrangement and safe operation of equipment and pipelines for nuclear facilities. http://docs.cntd.ru/document/1200044519.

[15] GOST R 58328-18. Piping of nuclear power plants. "Leak before break" concept.

[16] JSC IPPE. Technical specification E.091.7372.05 TU.

[17] JSC IPPE. Technical specification E.091.7326.01 TU.

[18] NP-010-16. Rules of design and operation of localizing devices for NPP. https://files.stroyinf.ru/Data2/1/4293755/429375579 3.htm.

[19] Peter the Great St. Petersburg Polytechnic University, LLE "SPE "DIAPROK". About weak points of LBB Concept application to reactor coolant circuit of old and new generation NPP Units. Scientific and technical report. 2018.

\section{About the authors}

Alexander A. Arzhaev, LLE "SPE "DIAPROK". E-mail: arzhaev.alexander@yandex.ru.

Alexey I. Arzhaev, LLE "SPE "DIAPROK". E-mail: arjaev@diaprok.msk.ru.

Valentin O. Makhanev, LLE "SPE "DIAPROK", Candidate of Technical Sciences. E-mail: v.makhanev@gmail.com.

Mikhail I. Antonov, Peter the Great St. Petersburg Polytechnic University. E-mail: antonov-mi@yandex.ru.

Anton V. Emelianov, Peter the Great St. Petersburg Polytechnic University. E-mail: em-ant1990@yandex.ru.

Aleksander A. Kalyutik, Peter the Great St. Petersburg Polytechnic University, Candidate of Technical Sciences, docent.E-mail:kalyutik@yandex.ru.

Yury E. Karyakin, Peter the Great St. Petersburg Polytechnic University, Doctor of Physical and Mathematical Sciences, professor. E-mail: yu kar@mail.ru.

Kirill A. Arzhaev, ANO "International Nuclear Safety Center”. E-mail: arzhaevk@insc.ru.

Ilya N. Denisov, ANO "International Nuclear Safety Center", Candidate of Technical Sciences. E-mail: denisov@insc.ru. 